\title{
Host choice and host leaving in Rhopalosiphum padi (Hemiptera: Aphididae) emigrants and repellency of aphid colonies on the winter host
}

\author{
R. Glinwood and J. Pettersson* \\ Department of Entomology, Swedish University of Agricultural Sciences, \\ PO Box S-750 07, Uppsala, Sweden
}

\begin{abstract}
Host choice and winter-host leaving in emigrants of bird cherry-oat aphid, Rhopalosiphum padi (Linnaeus), were investigated in the laboratory. In settling choice tests, emigrants collected from the winter host, Prunus padus, preferred this plant over a summer host, oats. Emigrants which had left P. padus for up to $24 \mathrm{~h}$ did not express a preference as a group, and those which had left for 24-48 h preferred oats. Eighty seven percent of emigrants caged as fourth-instar nymphs on P. padus leaves abandoned the host by the second day of adult life, and apparently did not subsequently return to the leaf. In an olfactometer, $P$. padus leaves which had supported spring generations of $R$. padi were repellent to emigrants. Volatiles were entrained from uninfested and R. padi-infested P. padus using cut twigs in the laboratory as well as intact twigs on a tree in the field. Entrainment extracts from uninfested $P$. padus had no effect on emigrants in the olfactometer, whereas those from twigs infested with nymphal emigrants were repellent. The study indicates that in $R$. padi, host-alternation is driven by behavioural changes which occur in individuals as well as between morphs.
\end{abstract}

\section{Introduction}

The bird cherry-oat aphid Rhopalosiphum padi (Linnaeus) (Hemiptera: Aphididae) is, in northern Europe, a host alternating species that migrates between winter and summer host plants. In the spring, eggs hatch on the winter host, Prunus padus (Rosaceae), and the aphids pass through two or three wingless generations before the appearance of the winged emigrant morph (Wiktelius, 1984). The emigrants develop as nymphs on $P$. padus and, after becoming adult, fly to the summer hosts, grasses and cereals (Poaceae), where they give rise to further parthenogenetic generations (Mordwilko, 1907; Wiktelius et al., 1990). The

\footnotetext{
*Author for correspondence

Fax: + 4618672890

E-mail: jan.pettersson@entom.slu.se
}

emigrant therefore lives and feeds on two taxonomically different hosts during its life.

Rhopalosiphum padi populations on $P$. padus increase during May, emigrants begin to leave, and by mid-summer no aphids remain on the plant (Dixon, 1971). The production of winged emigrants is induced both by crowding and poor nutritional quality of the leaves (Dixon \& Glen, 1971; Leather \& Lehti, 1982; Wiktelius, 1984), and it has been suggested that a change in the aphids intrinsic host preference causes the switch between winter and summer hosts. A considerable amount of work has been devoted to study of the factors contributing to reproductive success and flight capacity of winged morphs, for example fat body content, reproduction and autolysis of wing muscles (Dixon, 1971, 1976; Leather et al., 1983; Walters \& Dixon, 1983). However, the influence of different stimuli on the shift in host plant preference in individual emigrants 
has not received much attention. The irreversible change in host preference shown by emigrants, born on the winter host and moving to the summer host, is less common among herbivores. Hypothetically it can be explained either by an intrinsic change in preferences related to physiological age, or to a more complex mechanism where several factors, including probing/feeding experienced, play a priming role.

The behavioural ecology of R. padi is influenced by odour stimuli. For emigrants, responses to an aggregation pheromone and a repellent winter host component, methyl salicylate, have been demonstrated (Pettersson, 1994; Pettersson et al., 1994). However, studies of the chemical ecology of $R$. padi have mainly focused on the summer forms and on the remigrants (Pettersson, 1993; Hardie et al., 1994; Quiroz et al., 1997), and the role of semiochemicals for the spring generations on $P$. padus is not well understood.

This study examines in more detail the behavioural and chemical ecology of $R$. padi emigrants. The switch in host preference was investigated in adult emigrants, and the presence of aphid-induced repellent volatiles from the winter host is reported, based on entrainment from P. padus in the laboratory and field, and subsequent behavioural bioassay.

\section{Materials and methods}

\section{Aphids and plants}

Spring morphs of $R$. padi were reared on 4-year-old, $P$. padus saplings, planted in raised beds filled with potting soil (Hasselfors Garden) in an outdoor nethouse under ambient environmental conditions. Non-aphid-infested saplings were maintained under identical conditions. Spring morphs hatched from eggs which were deposited onto the trees by mating females the previous autumn. After hatching, aphids passed through two generations before emigrants were born. Oats, Avena sativa cv. Sanna, were grown in a glasshouse at $20 \pm 2^{\circ} \mathrm{C}, 16 \mathrm{~L}: 8 \mathrm{D}$.

\section{Host leaving of emigrants}

Rhopalosiphum padi emigrants were collected from P. padus saplings as fourth-instar nymphs (identifiable by the presence of wing buds), and transferred to uninfested saplings in a nethouse. A group of between five and seven leaves were enclosed in a perforated plastic bag (Cryovac, W.R. Grace Ltd, Cambridge, England) and a single aphid introduced. The bag prevented the aphids from leaving the space around the leaf, while allowing them to disperse freely from the leaf after they became winged. Three $P$. padus saplings were used, with ten aphids on each. Aphids were examined several times each day and the number of days after the adult moult on which the aphid flew from the leaf, and later died was recorded.

\section{Host preference of emigrants}

Emigrants were collected from P. padus saplings as fourthinstar nymphs and placed on uninfested saplings in a nethouse, enclosed on separate leaves using clip cages. Aphids were collected for the experiment at three stages: (i) before leaving the leaf; (ii) having left the leaf for up to $24 \mathrm{~h}$; and (iii) having left the leaf for 24-48 h. Having abandoned the winter host, $R$. padi emigrants did not return to that plant (R. Glinwood, personal observation). A settling choice bioassay was used to determine host preference. A single excised P. padus leaf and a single excised oat leaf were placed side by side on a filter paper disc, and were enclosed under a plastic ring (10 $\mathrm{cm}$ diameter with a mesh lid). Emigrants were released individually between the two leaves, and the plant on which they settled was recorded after $2 \mathrm{~h}$. A total of 30 aphids from each experimental group were tested, and the distributions of settling preferences were compared using Chi-square tests.

\section{Entrainment of P. padus volatiles - laboratory experiments}

Volatiles were entrained from aphid-infested and uninfested $P$. padus twigs. These were cut, and stood in a beaker of distilled water sealed with Parafilm. The twig was inserted through the Parafilm, and the insertion point was also sealed. Air was dried and purified by passage through activated charcoal and $4 \AA$ molecular sieve, and was drawn at $300 \mathrm{ml} \mathrm{min}^{-1}$ through a glass vessel $(26 \mathrm{~cm}$ high $\times 9.5 \mathrm{~cm}$ diameter) containing the P. padus for $72 \mathrm{~h}$. Volatiles were entrained onto Porapak Q, which had been washed with diethyl ether and heated at $150^{\circ} \mathrm{C}$, and subsequently desorbed by elution with diethyl ether. Extracts were concentrated at room temperature under a stream of nitrogen and stored in a refrigerator at $5^{\circ} \mathrm{C}$. Entrainments were made from $P$. padus four weeks after leaf emergence, and the plant was either uninfested or infested with a colony of $R$. padi emigrants in the nymphal instars.

\section{Entrainment of P. padus volatile - field experiments}

Entrainments were made in situ from an uninfested twig, and from a twig infested with mixed instar nymphal emigrants, in the same area of the canopy of a P. padus tree (16 years old, $6 \mathrm{~m}$ tall) in the field for $48 \mathrm{~h}$ between 12 and 14 May 1999. A twig (approximately $20 \mathrm{~cm}$ long) was enclosed in a bag made from inert plastic (Cryovac Cellophane). The bag was sealed at one end, and the other held a stopper made from a disc of inert polythene foam plastic (Plastazote PZ940). The stopper had inlets for an air inlet tube containing activated charcoal and $4 \AA$ molecular sieve, the twig, and for the Porapak $Q$ containing tube. The area around the inlets was sealed using Teflon tape. Air was drawn through the bag at $11 \mathrm{~min}^{-1}$ using a vacuum pump connected to an exterior power supply. Volatiles were extracted as above.

\section{Olfactometer bioassay}

Extracts of infested and uninfested P. padus were tested for their behavioural effects on adult $R$. padi emigrants in a four-way olfactometer (Pettersson, 1970), consisting of an enclosed perspex arena (12 cm diameter) with a central chamber and four side arms. Air was drawn from the centre of the olfactometer using a water pump $\left(3 \mathrm{ml} \mathrm{sec}^{-1}\right)$, establishing discrete air currents in the side arms, and an odour field was created by introducing the air entrainment extract in diethyl ether $(10 \mu l$ extract applied to a filter paper square) to one of the side arms. To avoid saturating the atmosphere in the olfactometer with solvent, control arms 
contained untreated filter paper. However, a separate test showed that diethyl ether alone was neither attractive nor repellent to the aphids (Chi-square test; $\mathrm{n}=16, \chi^{2}=0.02, P$ $>0.05)$. Tests were also run with living material, which was either a $P$. padus leaf with eight fourth instar emigrants (infested for $48 \mathrm{~h}$ ), emigrants alone, or a previously infested leaf (10-30 nymphal emigrants for 2 weeks) with the aphids removed and the surface cleaned by gentle washing with damp cotton wool. In these tests, control arms contained clean air.

A single adult migrant (which had left $P$. padus for up to $24 \mathrm{~h}$ ) was introduced into the olfactometer, and its position recorded every $3 \mathrm{~min}$ for $30 \mathrm{~min}$. The distribution of aphid visits to the treatment arm and mean of the control arms was compared using Chi-square tests. Experiments were repeated 14-22 times over at least two days, with the olfactometer turned through $90^{\circ}$ between replicates to avoid positional bias.

\section{Results}

\section{Host leaving of emigrants}

The majority (87\%) of emigrants left the leaves of P. padus by the second day after becoming adult (table 1). By the third day of adult life, all aphids had left the leaves. Aphid mortality increased rapidly after leaving the leaf (table 1), suggesting that, although no alternative source of food or water was available, the emigrants did not return to $P$. padus.

Table 1. Effect of adult age on host leaving and mortality of Rhopalosiphum padi emigrants confined around the winter host plant Prunus padus inside perforated polythene bags $(\mathrm{n}=30)$.

\begin{tabular}{lcc}
\hline${\text { Adult life }(\text { days })^{1}}^{1}$ & \% Aphids on leaf & \% Mortality \\
\hline 1 & 100 & 0 \\
2 & 13 & 0 \\
3 & 0 & 57 \\
4 & 0 & 87 \\
5 & 0 & 97 \\
\hline
\end{tabular}

${ }^{1}$ Number of days after the aphid had become adult (i.e. winged).

\section{Host preference of emigrants}

When emigrants were collected before leaving the winter host, $P$. padus, significantly more individuals settled on $P$. padus leaves (Chi-square test; $\mathrm{n}=30, \chi^{2}=10.8, P<0.01$ ) than on oat leaves (table 2). Emigrants that had left $P$. padus for up to $24 \mathrm{~h}$ without contacting summer hosts did not settle in significantly greater numbers on either plant (Chisquare test; $\mathrm{n}=30, \chi^{2}=1.2, P>0.05$ ) (table 2). Emigrants which had left $P$. padus for between 24 and $48 \mathrm{~h}$ without contacting summer hosts settled in significantly greater numbers on oats (Chi-square test; $\mathrm{n}=30, \chi^{2}=19.2$, $P<0.001$ ) than on P. padus (table 2).

\section{Olfactometry with volatiles}

Prunus padus leaves infested with eight fourth-instar emigrants for $48 \mathrm{~h}$ had no effect on adult emigrants in the olfactometer (Chi-square test; $\mathrm{n}=14, \chi^{2} 1.4, P>0.05$ ) (table 3). However, leaves which had been infested with 10-30 mixed instar nymphal emigrants for two weeks were significantly repellent (Chi-square test; $\mathrm{n}=18, \chi^{2}=5.7, P$ $<0.05$ ) (table 3). Eight fourth-instar migrants alone had no effect on adult emigrants (Chi-square test; $\mathrm{n}=18, \chi^{2}=0.01$, $P>0.05)$ (table 3).

Air entrainment extract containing volatiles of an uninfested, cut $P$. padus twig had no effect on the behaviour of adult emigrants (Chi-square test; $\mathrm{n}=18, \chi^{2}=0.3$, $P>0.05$ ) (table 4 ). However, extract containing volatiles of a cut twig infested with fourth instar emigrants was

Table 2. Host preference of Rhopalosiphum padi emigrants before and after leaving the winter host plant Prunus padus, when offered leaves of $P$. padus and a summer host, oats.

\begin{tabular}{lcrrrr}
\multirow{2}{*}{$\begin{array}{l}\text { Test } \\
\text { aphids }\end{array}$} & \multicolumn{2}{c}{$\begin{array}{l}\text { No. aphids settled } \\
\text { after 2 } \mathrm{h}(\mathrm{n}=30)\end{array}$} & $\chi^{2}$ & $P$ \\
\cline { 2 - 3 } & P. padus & Oat & & & \\
\hline Before leaving P. padus & 24 & 6 & 10.8 & $<0.01$ \\
Off P. padus <24 h & 18 & 12 & 1.2 & $>0.05$ \\
Off P. padus 24-48 h & 3 & 27 & 19.2 & $<0.001$ \\
\hline
\end{tabular}

Table 3. Responses of Rhopalosiphum padi emigrants to odours of leaves of the winter host Prunus padus and conspecific aphids in a fourway olfactometer.

\begin{tabular}{|c|c|c|c|c|c|}
\hline Test stimulus ${ }^{1}$ & Mean no. visits in olfactometer arm & $\mathrm{n}$ & $x^{2}$ & $P$ & $\begin{array}{c}\chi^{2} \text { value for } \\
\text { heterogeneity }\end{array}$ \\
\hline $\begin{array}{l}\text { P. padus leaf infested with } \\
\text { eight fourth nymphal instar } \\
\text { emigrants for } 48 \mathrm{~h}\end{array}$ & 1.9 & \multirow[t]{2}{*}{14} & \multirow[t]{2}{*}{1.4} & \multirow[t]{2}{*}{$>0.05$} & \multirow[t]{2}{*}{6.1} \\
\hline Control & 2.6 & & & & \\
\hline $\begin{array}{l}\text { P. padus leaf previously infested } \\
\text { with 10-30 nymphal emigrants }\end{array}$ & & \multirow{3}{*}{18} & \multirow{3}{*}{5.7} & \multirow{3}{*}{$<0.05$} & \multirow{3}{*}{13.0} \\
\hline for 2 weeks (aphids removed) & 1.6 & & & & \\
\hline Control & 2.8 & & & & \\
\hline $\begin{array}{l}\text { Eight fourth nymphal instar } \\
\text { emigrants }\end{array}$ & 2.6 & \multirow{2}{*}{18} & \multirow{2}{*}{0.01} & \multirow{2}{*}{$>0.05$} & \multirow{2}{*}{3.5} \\
\hline Control & 2.5 & & & & \\
\hline
\end{tabular}

${ }^{1}$ Control arms contained clean air.

${ }^{2}$ All values of $\chi^{2}$ for heterogeneity are non-significant. 
Table 4. Responses of Rhopalosiphum padi emigrants to volatiles entrained from winter host Prunus padus which was either uninfested, or infested with conspecific aphids in a four-way olfactometer.

\begin{tabular}{|c|c|c|c|c|c|}
\hline Air entrainment extract ${ }^{1}$ & Mean no. visits in olfactometer arm & $\mathrm{n}$ & $x^{2}$ & $P$ & $\chi^{2}$ value for heterogeneity ${ }^{2}$ \\
\hline Cut, uninfested P. padus twig & 2.8 & \multirow[t]{2}{*}{18} & \multirow[t]{2}{*}{0.3} & \multirow[t]{2}{*}{$>0.05$} & \multirow[t]{2}{*}{6.1} \\
\hline Control & 2.4 & & & & \\
\hline $\begin{array}{l}\text { Cut, } P \text {. padus twig infested with } \\
\text { fourth instar nymphal emigrants }\end{array}$ & 1.7 & \multirow{2}{*}{20} & \multirow[t]{2}{*}{5.0} & \multirow[t]{2}{*}{$<0.05$} & \multirow[t]{2}{*}{12.5} \\
\hline Control & 2.8 & & & & \\
\hline $\begin{array}{l}\text { Uninfested } P \text {. padus twig in situ } \\
\text { on a field tree }\end{array}$ & 2.8 & \multirow[t]{2}{*}{19} & \multirow[t]{2}{*}{0.3} & \multirow[t]{2}{*}{$>0.05$} & \multirow[t]{2}{*}{11.8} \\
\hline Control & 2.4 & & & & \\
\hline $\begin{array}{l}\text { P. padus twig infested with } \\
\text { nymphal instar emigrants } \\
\text { in situ on a field tree }\end{array}$ & 1.8 & \multirow[t]{2}{*}{22} & \multirow[t]{2}{*}{4.0} & \multirow[t]{2}{*}{$<0.05$} & \multirow[t]{2}{*}{12.3} \\
\hline Control & 2.7 & & & & \\
\hline
\end{tabular}

${ }^{1}$ Extract of entrained volatiles in diethyl ether. Control arms contained clean air.

${ }^{2}$ All values of $\chi^{2}$ or heterogeneity are non-significant.

significantly repellent to adult emigrants (Chi-square test; $\mathrm{n}=20, \chi^{2}=5.0, P<0.05$ ) (table 4 ). An extract containing volatiles entrained in situ from an uninfested P. padus twig on a tree in the field had no behavioural effect on adult emigrants (Chi-square test; $\mathrm{n}=19, \chi^{2}=0.3, P>0.05$ ) (table 4 ), whereas the extract containing volatiles collected in situ from a twig infested with mixed instar nymphal emigrants was significantly repellent (Chi-square test; $\mathrm{n}=$ $\left.22, \chi^{2}=4.0, P<0.05\right)($ table 4$)$.

\section{Discussion}

The switching of hosts in host-alternating aphids requires, at some stage of the life cycle, a modification in the host plant preference of the aphid itself. The present study shows that, in the spring, the change in host preference occurs within individuals of $R$. padi. It is not simply explained as a difference between generations born on the winter host. The switch in host preference from winter to summer host did not occur sharply at the adult moult, but formed gradually during the early stages of adult life. Among the group which had left $P$. padus for up to $24 \mathrm{~h}$, some aphids chose the winter host and some the summer host. This suggests that the change in host preference occurs within individuals over a period of hours, rather than days. The change could be mediated by levels of juvenile hormone in the aphid's body (Hardie, 1981; Hardie \& Glascodine, 1990). In remigrants of the black bean aphid Aphis fabae Scopoli (Hemiptera: Aphididae), Hardie (1981) found that larval instars preferred the summer host, whereas adult remigrants preferred the winter host. However, in this study adults were tested on day 2 after the final moult.

Also linked to time after the adult moult in this study was the behaviour of the aphids caged on P. padus. On day 1, all the adult aphids were settled on the leaf, but by day $2,87 \%$ had abandoned the leaf and had settled elsewhere in the cage. After becoming adult, flight muscles may require time to develop fully. In pea aphid, Acyrthosiphon pisum (Harris) (Hemiptera: Aphididae), the flight muscle protein content of winged summer morphs reached a peak two days after the adult moult, and this coincided with take-off by the aphids (Kobayashi \& Ishikawa, 1993). In the current study, most of the aphids had died by day 4 , an indication that they did not return to the leaf, even to feed briefly or to ingest fluid. If emigrants do not accept $P$. padus again once the preference for summer hosts has formed, this would ensure that migrating $R$. padi do not accidentally recolonize the winter host after leaving it.

It is interesting that the majority of emigrants left P. padus before the preference for the summer host would have been completely formed. Therefore it is possible that an innate switch in host preference is not a causal mechanism in host alternation (Dixon, 1971). However, although the host leaving experiment was performed in a semi-open nethouse, exposed to ambient temperatures, the host leaving pattern can still be regarded as representing what may happen under 'ideal' conditions. Wind and rain, for example, would probably delay the flight of emigrants from the winter host under natural field conditions (Dixon \& Mercer, 1983). Moreover, it is possible that a period of flight activity after leaving P. padus accelerates the change in host preference.

The olfactometer results indicate that volatiles associated with the infestation of $P$. padus by spring morphs are repellent to emigrants. Aphids alone were not repellent, and a light infestation (8 aphids) for $48 \mathrm{~h}$ was insufficient to render a leaf repellent. Heavier infestations (10-30 aphids) over a longer period did cause leaves to become repellent in the olfactometer, even after aphids were removed from them. Volatiles from uninfested P. padus were not repellent. Therefore the repellency appears to be induced by aphid infestation. In the context of the R. padi life cycle, this may be an additional mechanism ensuring that emigrants do not recolonize the winter host after leaving it. The repellent volatiles might also contribute to the actual leaving of the plant by the emigrants, but this has not been demonstrated. Rhopalosiphum padi usually exists at mixed stages of development on P. padus in the spring, so adult emigrants are likely to take off from colonies which have feeding nymphal emigrants, or even foundress morphs present. It is possible that the concentration of behaviourally active volatiles in the extracts are higher than would be emitted by an aphid colony/twig in the field, and the olfactometer results should be considered in the light of this possibility. However, it can be noted that there would normally be 
many such aphid colonies/twigs on a single tree which may raise the level of volatiles experienced by the aphids.

Rhopalosiphum padi colonization of cereal fields has already been successfully reduced by release of methyl salicylate, a volatile component of $P$. padus which is repellent to this and other cereal aphids (Pettersson et al., 1994). Identification of the substances responsible for the repellent effects reported here may yield further candidates for use in crop protection. This study indicates that factors which influence host preference and winter host leaving by emigrants operate at the level of the individual aphid, as well as the aphid morph.

\section{Acknowledgements}

This study was supported financially by a grant from the faculty of Agriculture, Landscape Architecture and Horticulture, Swedish University of Agricultural Sciences, and the Swedish Foundation for Strategic Environmental Research (MISTRA)

\section{References}

Dixon, A.F.G. (1971) The life-cycle and host preferences of the bird cherry-oat aphid, Rhopalosiphum padi L., and their bearing on the theories of host alternation in aphids. Annals of Applied Biology 68, 135-147.

Dixon, A.F.G. (1976) Reproductive strategies of the alate morphs of the bird cherry-oat aphid Rhopalosiphum padi L. Journal of Animal Ecology 45, 817-830.

Dixon, A.F.G. \& Glen, D.M. (1971) Morph determination in the bird cherry-oat aphid, Rhopalosiphum padi L. Annals of Applied Biology 68, 11-21.

Dixon, A.F.G. \& Mercer, D.R. (1983) Flight behaviour in the sycamore aphid: actors affecting take-off. Entomologia Experimentalis et Applicata 33, 43-49.

Hardie, J. (1981) The effect of juvenile hormone on host-plant preference in the black bean aphid, Aphis fabae. Physiological Entomology 6, 369-374.

Hardie, J. \& Glascodine, J. (1990) Polyphenism and host-plant preference in the black bean aphid, Aphis fabae Scop. Acta Phytopathologica et Entomologica Hungarica 25, 323-330.

Hardie, J., Storer, J.R., Nottingham, S.F., Peace, L., Harrington, R., Merritt, L., Wadhams, L.J. \& Wood, D.K. (1994) The interaction of sex pheromone and plant volatiles for field attraction of male bird-cherry aphid, Rhopalosiphum padi. Proceedings of the Brighton Crop Protection Conference, Pests and Diseases 3, 1223-1230.

Kobayashi, M. \& Ishikawa, H. (1993) Breakdown of indirect flight muscles of alate aphids (Acyrthosiphon pisum) in relation to their flight, feeding and reproductive behavior. Journal of Insect Physiology 39, 549-554.
Leather, S.R. \& Lehti, J.P. (1982) Field studies on the factors affecting the population dynamics of the bird cherry-oat aphid Rhopalosiphum padi (L.) in Finland. Annales Agriculturae Fenniae 21, 20-31.

Leather, S.R., Wellings, P.W. \& Dixon, A.F.G. (1983) Habitat quality and the reproductive strategies of the migratory morphs of the bird cherry-oat aphid, Rhopalosiphum padi (L.), colonizing secondary host plants. Oecologia 59, 302-306.

Mordwilko, A. (1907) Die zyklische Fortpflanzung der Pflanzenläuse: II. Die Migrationen der Pflanzenlause, ihre Ursachen und ihre Entstehung. Biologisches Zentralblatt 24, 769-816.

Pettersson, J. (1970) Studies on Rhopalosiphum padi (L.). Laboratory studies on olfactometric responses to winter host Prunus padus L. Lantbrukshögskolans Annaler 36, 381-399.

Pettersson, J. (1993) Odour stimuli affecting autumn migration of Rhopalosiphum padi (L.) (Hemiptera: Homoptera). Annals of Applied Biology 122, 417-425.

Pettersson, J. (1994) The bird cherry-oat aphid, Rhopalosiphum padi (L.) (Homoptera: Aphididae.) and odours. pp. 3-12 in Leather, S.R., Watt, A.D., Mills, N.J. \& Walters, K.F.A. (Eds) Individuals, populations and patterns in ecology. Andover, Intercept Ltd.

Pettersson, J., Pickett, J.A., Pye, B.J., Quiroz, A., Smart, L.E., Wadhams, L.J. \& Woodcock, C.M. (1994) Winter host component reduces colonisation by bird-cherry-oat aphid, Rhopalosiphum padi (L.) (Homoptera, Aphididae), and other aphids in cereal fields. Journal of Chemical Ecology 20, 2565-2574.

Quiroz, A., Pettersson, J., Pickett, J.A., Wadhams, L.J. \& Niemeyer, H.M. (1997) Semiochemicals mediating spacing behavior of bird cherry-oat aphid, Rhopalosiphum padi feeding on cereals. Journal of Chemical Ecology 23, 2599-2607.

Walters, K.F.A. \& Dixon, A.F.G. (1983) Migratory urge and reproductive investment in aphids: variation within cones. Oecologia 58, 70-75.

Wiktelius, S. (1984) Studies on population development on the primary host and spring migration of Rhopalosiphum padi (L.) (Hom., Aphididae). Zeitschrift für Angewandte Entomologie 97, 217-222.

Wiktelius, S., Weibull, J. \& Pettersson, J. (1990) Aphid host plant ecology: the bird cherry-oat aphid as a model. pp. 21-36 in Campbell, R.K. \& Eikenbary, R.D. (Eds) Aphid-plant genotype interactions. B.V. Amsterdam, Elsevier Science Publishers.

(Accepted 25 January 2000)

(c) CAB International, 2000 
